\title{
The Unique Substance, Lidocaine and Biological Activity of the Dioscorea Species for Potential Application as a Cancer Treatment, Natural Pesticide and Product
}

\author{
Warin Wonok ${ }^{1}$, Arunrat Chaveerach ${ }^{1}$, Pornnarong Siripiyasing ${ }^{2}$, Runglawan Sudmoon ${ }^{3}$ and Tawatchai Tanee ${ }^{4, *}$ \\ 1 Department of Biology, Faculty of Science, Khon Kaen University, Khon Kaen 40002, Thailand; \\ warin1104@hotmail.com (W.W.); raccha@kku.ac.th (A.C.) \\ 2 Faculty of Science and Technology, Rajabhat Mahasarakham University, Maha Sarakham 44000, Thailand; \\ psiripiyasing@gmail.com \\ 3 Faculty of Law, Khon Kaen University, Khon Kaen 40002, Thailand; rungla@kku.ac.th \\ 4 Faculty of Environment and Resource Studies, Mahasarakham University, Maha Sarakham 44150, Thailand \\ * Correspondence: tawatchai5@hotmail.com
}

Citation: Wonok, W.; Chaveerach, A.; Siripiyasing, P.; Sudmoon, R.; Tanee, $\mathrm{T}$. The Unique Substance, Lidocaine and Biological Activity of the Dioscorea Species for Potential Application as a Cancer Treatment, Natural Pesticide and Product. Plants 2021, 10, 1551. https://doi.org/ 10.3390/plants10081551

Academic Editors:

Rodica-Mihaela Dinică and

Bianca Furdui

Received: 11 July 2021

Accepted: 26 July 2021

Published: 28 July 2021

Publisher's Note: MDPI stays neutral with regard to jurisdictional claims in published maps and institutional affiliations.

Copyright: (c) 2021 by the authors. Licensee MDPI, Basel, Switzerland. This article is an open access article distributed under the terms and conditions of the Creative Commons Attribution (CC BY) license (https:/ / creativecommons.org/licenses/by/ $4.0 /)$.
Abstract: The six Dioscorea species, D. brevipetiolata, D. bulbifera, D. depauperata (Dd), D. glabra (Dg), D. pyrifolia and D. hamiltonii were analyzed for phytochemicals, toxicity in PBMCs, and biological activity in two cancer cell lines by MTT and comet assays, and pesticide efficiency. Via GC-MS, lidocaine was found to be the predominant compound in two of the studied species. To confirm the systematics, lidocaine was also found in lower amounts in 11 species. The MTT assay showed no toxicity in all six of the studied species. The comet assay showed the key result that the ethanol extracts of $D d$ and $D g$ violently broke DNA into pieces. Biological activity of these two species' extracts showed toxicity on HepG2 and no effects on HCT-116. The water extracts of $D d$ and $D g$, applied to Brassica chinensis showed high efficiency as a bioprotectant. In summary, lidocaine seems to be the predominant identifying compound of the genus Dioscorea in Thailand, which is useful in systematics. At least the two species, $D d$ and $D g$, may be used for human hepatocyte cancer treatment and as an alternative pesticide for economically important vegetables. Dioscorea species containing lidocaine or extracted lidocaine have promise for natural product creation.

Keywords: Brassica chinensis; Dioscorea depauperata; Dioscorea glabra; HepG2; HCT-116; human hepatocyte cancer; insect bioprotectant efficiency; lidocaine

\section{Introduction}

There are 42 Dioscorea species in Thailand [1]. They always contain two important substances-dioscorine and the steroidal sapogenin diosgenin, which are both toxic [2-4]. Some species' tubers have been used for food, for example $D$. hispida, which is very poisonous due to its dioscorine levels which cause dizziness and spasms, but special processing methods such as slicing into thin pieces, soaking them in running water for 2-3 days, and then placed in a stream to leach toxins, have been used to make them edible. The raw tuber is used as an ingredient for animal poisons, insecticides and wound medicine [5]. There are three species, D. bulbifera, D. hispida, and D. membranacea Pierre in Thailand recorded as traditional medicine, and one of these, D. membranacea, had its medicinal properties supported by a biological activity report [2]. The substance diosgenin, found in some species, has several bioactivities as reported by Jesus et al. [3] and Kumar et al. [6], including anticancer activity, anti-inflammatory, immunological activity, anti-infectious activity, effects in diabetes, dyslipidemias, and obesity, anticoagulant and antithrombotic effects, protection of cardiac cells from hypoxia-reoxygenation injury, and antioxidative effects. Aside from the tuber, bulbils or aerial bulbs have also long been used in several ways, such as D. bulbifera bulbils which are used in the treatment as of dysentery, syphilis, ulcers, cough, leprosy, diabetes, asthma, and cancer [2,7]. Recently, Padhan and Panda [8] 
revealed that Dioscorea species provides food and medicines in relation to their nutritional, anti-nutritional and pharmacological properties and highlights the potentiality for food and nutritional security for combating the "hidden hunger" caused by micronutrient deficiencies. Although there are many Dioscorea species worldwide, there is very little scientific information on them. Therefore, this research aimed to gain knowledge of certain Dioscorea species including phytochemicals, toxicity, biological activity, and usages in human life.

\section{Results}

\subsection{Phytochemicals Constituent}

\subsubsection{Gas Chromatography-Mass Spectrometry (GC-MS)}

Phytochemicals found in the six studied Dioscorea species, D. brevipetiolata, D. bulbifera, D. depauperata, D. glabra, D. pyrifolia and D. hamiltonii, by GC-MS analysis are shown in various types and quantities in Table 1 and chromatograms showing retention time and peak areas are show in Figure 1. Major quantities of phytol, $\gamma$-sitosterol, stigmasterol, and squalene were found, and minor quantities were found of other substances. The surprising finding was that the dominant substance was lidocaine, at $0.81 \%$ and $1.03 \%$ in D. depauperata and D. glabra.

Table 1. A summary of chemical constituents indicated by relative content percentages analyzed by gas chromatographymass spectrometry in the six hexane $(\mathrm{H})$ and ethanol (E) Dioscorea species leaf extracts.

\begin{tabular}{|c|c|c|c|c|c|c|c|c|c|c|c|c|c|}
\hline \multirow{3}{*}{ Compound } & \multirow{3}{*}{ Formula } & \multicolumn{12}{|c|}{ Relative Content (\%) } \\
\hline & & \multicolumn{2}{|c|}{ D. brevipetiolata } & \multicolumn{2}{|c|}{ D. bulbifera } & \multicolumn{2}{|c|}{ D. depauperata } & \multicolumn{2}{|c|}{ D. glabra } & \multicolumn{2}{|c|}{ D. hamiltonii } & \multicolumn{2}{|c|}{ D. pyrifolia } \\
\hline & & $\mathbf{H}$ & $\mathbf{E}$ & $\mathbf{H}$ & $\mathrm{E}$ & $\mathbf{H}$ & $\mathbf{E}$ & $\mathbf{H}$ & $\mathbf{E}$ & $\mathbf{H}$ & $\mathbf{E}$ & $\mathbf{H}$ & $\mathbf{E}$ \\
\hline Phytol & $\mathrm{C}_{20} \mathrm{H}_{40} \mathrm{O}$ & 24.15 & 56.90 & 47.47 & 48.23 & 46.06 & 50.22 & 31.81 & 47.56 & 16.23 & 41.95 & 10.78 & 44.35 \\
\hline Phytol, acetate & $\mathrm{C}_{22} \mathrm{H}_{42} \mathrm{O}_{2}$ & 0.97 & - & - & - & 4.62 & - & 1.31 & 10.48 & - & - & 0.63 & - \\
\hline$\gamma$-Sitosterol & $\mathrm{C}_{28} \mathrm{H}_{50} \mathrm{O}$ & 15.76 & 5.83 & 15.08 & 5.25 & - & 2.52 & 4.26 & 1.68 & 21.36 & 9.23 & 9.03 & 7.54 \\
\hline Stigmasterol & $\mathrm{C}_{29} \mathrm{H}_{48} \mathrm{O}$ & 9.97 & 3.69 & 12.72 & 10.44 & 2.96 & 1.53 & 2.40 & 0.81 & 11.06 & 4.81 & 2.71 & 2.18 \\
\hline Squalene & $\mathrm{C}_{30} \mathrm{H}_{50}$ & 10.80 & 3.97 & - & - & 4.51 & 0.87 & 4.87 & 0.86 & 4.89 & 2.04 & 10.20 & 6.39 \\
\hline Phenol, 2-propyl- & $\mathrm{C}_{11} \mathrm{H}_{17} \mathrm{NO}_{3}$ & - & - & - & - & - & 8.35 & - & 10.17 & - & - & - & - \\
\hline Vitamin E & $\mathrm{C}_{29} \mathrm{H}_{50} \mathrm{O}_{2}$ & 6.09 & 2.31 & 4.21 & 1.51 & 5.76 & - & 3.79 & 1.45 & 4.69 & 2.23 & - & 2.06 \\
\hline \multirow{2}{*}{$\begin{array}{l}\text { Triacontanoic acid, } \\
\text { methyl ester } \\
\text { dl- } \alpha \text {-Tocopherol }\end{array}$} & $\mathrm{C}_{31} \mathrm{H}_{62} \mathrm{O}_{2}$ & - & - & - & - & 7.82 & - & - & - & - & - & - & - \\
\hline & $\mathrm{C}_{29} \mathrm{H}_{50} \mathrm{O}_{2}$ & 3.07 & 1.17 & 1.75 & 0.85 & 3.81 & 0.95 & 6.61 & 1.39 & - & - & 2.04 & 1.68 \\
\hline $\begin{array}{l}\text { 2-Pentadecanone, } \\
\text { 6,10,14-trimethyl- }\end{array}$ & $\mathrm{C}_{18} \mathrm{H}_{36} \mathrm{O}$ & 4.27 & 2.15 & 5.46 & 2.75 & 3.16 & 1.32 & 2.00 & 1.10 & 6.75 & 4.19 & 2.18 & 1.91 \\
\hline \multirow{2}{*}{$\begin{array}{l}\text { Hexadecanoic acid, } \\
\text { ethyl ester } \\
\gamma \text {-Tocopherol }\end{array}$} & $\mathrm{C}_{18} \mathrm{H}_{36} \mathrm{O}_{2}$ & - & 2.19 & - & 2.71 & - & 1.73 & - & 2.07 & 1.23 & 1.99 & 0.43 & 6.14 \\
\hline & $\mathrm{C}_{28} \mathrm{H}_{48} \mathrm{O}_{2}$ & 1.60 & 0.81 & - & - & 2.39 & 0.72 & 5.84 & 1.65 & 1.27 & 0.73 & 0.99 & 0.91 \\
\hline $\begin{array}{l}\text { Campesterol } \\
\text { 1,3-Benzenediol }\end{array}$ & $\mathrm{C}_{28} \mathrm{H}_{48} \mathrm{O}$ & 4.46 & 1.82 & 3.82 & 1.34 & - & - & - & - & 6.18 & 2.67 & 1.39 & 1.22 \\
\hline $\begin{array}{l}\text { 1,3-benzenediol, } \\
\text { 4-propyl- }\end{array}$ & $\mathrm{C}_{9} \mathrm{H}_{12} \mathrm{O}_{2}$ & - & - & - & - & - & - & - & 4.90 & - & - & - & - \\
\hline \multirow{2}{*}{$\begin{array}{l}\delta \text {-Tocopherol } \\
\text { n-Hexadecanoic acid }\end{array}$} & $\mathrm{C}_{27} \mathrm{H}_{46} \mathrm{O}_{2}$ & - & - & - & - & - & - & 2.93 & 0.63 & - & - & - & - \\
\hline & $\mathrm{C}_{16} \mathrm{H}_{32} \mathrm{O}_{2}$ & - & - & - & 0.42 & - & 2.60 & - & 1.25 & - & - & - & - \\
\hline Dodecane & $\mathrm{C}_{12} \mathrm{H}_{26}$ & - & 1.67 & - & 1.57 & - & 1.47 & - & 2.23 & - & - & - & 1.58 \\
\hline \multirow{2}{*}{$\begin{array}{l}\text { Glycerol } \beta \text {-palmitate } \\
\text { Octadecanoic acid, ethyl } \\
\text { ester }\end{array}$} & $\mathrm{C}_{19} \mathrm{H}_{38} \mathrm{O}_{4}$ & - & 0.56 & - & 0.71 & - & 0.95 & - & 0.61 & - & 1.19 & - & - \\
\hline & $\mathrm{C}_{20} \mathrm{H}_{40} \mathrm{O}_{2}$ & - & - & - & 0.53 & - & - & - & - & - & - & - & 1.35 \\
\hline \multirow{2}{*}{$\begin{array}{l}\text { Tetradecane } \\
\text { Benzyldiethyl-(2,6- } \\
\text { xylylcarbamoylmethyl)- } \\
\text { ammonium benzoate }\end{array}$} & $\mathrm{C}_{14} \mathrm{H}_{30}$ & - & 4.45 & - & - & - & 2.07 & - & 2.80 & - & - & - & 2.13 \\
\hline & $\mathrm{C}_{28} \mathrm{H}_{34} \mathrm{~N}_{2} \mathrm{O}_{3}$ & - & 0.56 & - & 0.93 & - & - & - & - & - & 0.93 & - & 0.62 \\
\hline \multirow{3}{*}{$\begin{array}{l}\text { Lidocaine } \\
\text { Diisooctyl phthalate } \\
\text { 2-Hydroxy-5- } \\
\text { methylisophthalaldehyde }\end{array}$} & $\mathrm{C}_{14} \mathrm{H}_{22} \mathrm{~N} 2 \mathrm{O}$ & - & - & - & - & - & 0.81 & - & 1.03 & - & - & - & - \\
\hline & $\mathrm{C}_{24} \mathrm{H}_{38} \mathrm{O}_{4}$ & - & - & - & - & 1.22 & - & - & - & - & - & - & - \\
\hline & $\mathrm{C}_{9} \mathrm{H}_{8} \mathrm{O}_{3}$ & - & - & - & - & - & - & - & 0.80 & - & - & - & - \\
\hline \multirow{2}{*}{$\begin{array}{l}\text { Total of identified } \\
\text { compounds } \\
\text { Unknown }\end{array}$} & - & 81.14 & 88.08 & 90.51 & 77.24 & 82.31 & 76.11 & 65.82 & 93.47 & 73.66 & 71.96 & 40.38 & 80.06 \\
\hline & - & 18.86 & 11.92 & 9.49 & 22.76 & 17.69 & 23.89 & 34.18 & 6.53 & 26.34 & 28.04 & 59.62 & 19.94 \\
\hline
\end{tabular}



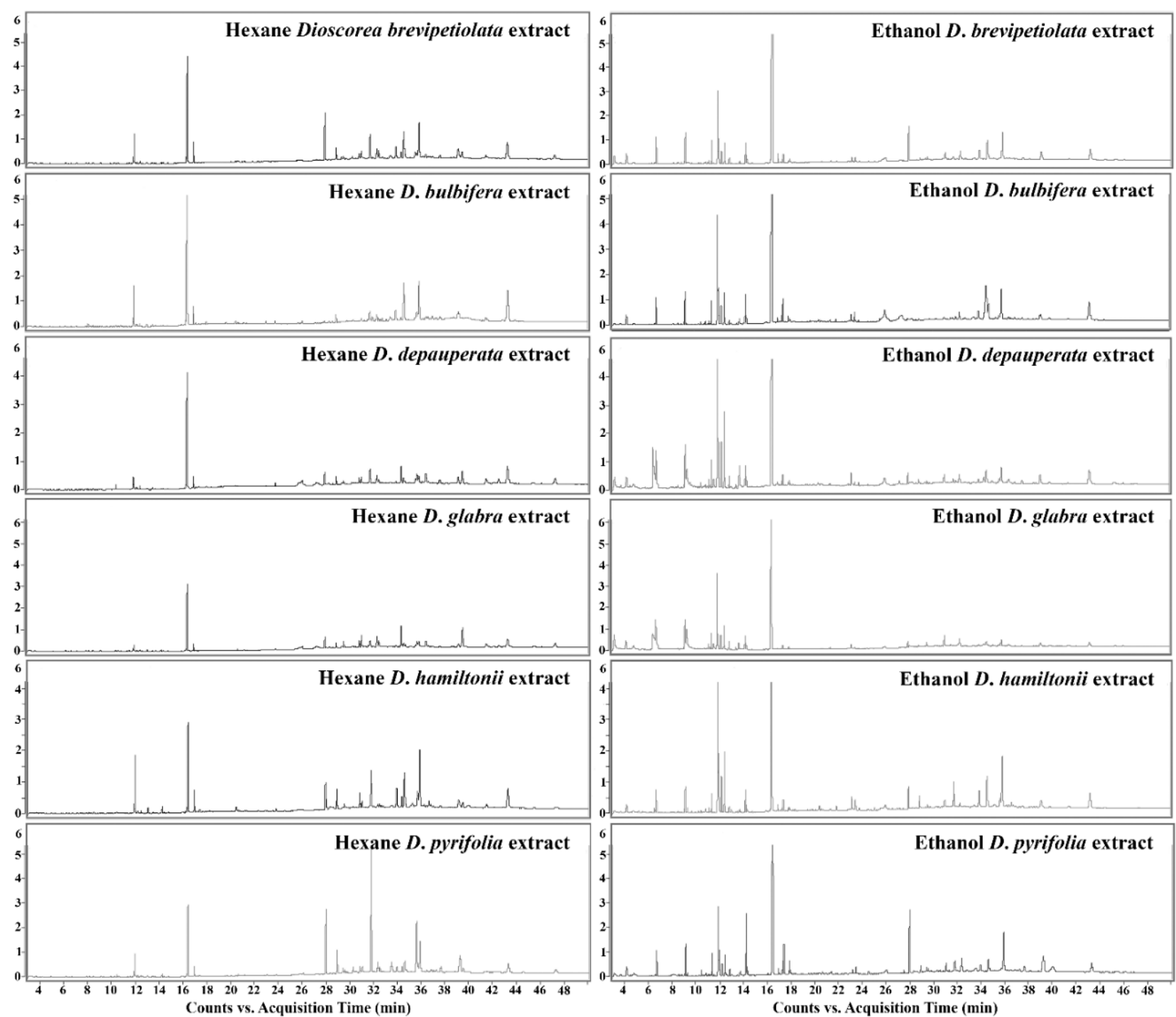

Figure 1. Gas chromatography-mass spectrometry chromatograms of the hexane and ethanol leaf extracts of six Dioscorea species showing retention time and peak areas.

\subsubsection{Gas Chromatography (GC) with the Lidocaine Standard}

When lidocaine was measured exactly by GC compared to the lidocaine standard in the 11 Dioscorea species, methanol extracts of D. alata, D. arachidna, D. brevipetiolata, D. bulbifera, D. decipiens, D. depauperata, D. esculenta, D. glabra, D. hamiltonii, D. hispida and D. pentaphylla, lidocaine content was found to range from $3.83 \times 10^{-3}$ to $2.32 \times 10^{-3} \mathrm{mg} / \mathrm{mL}$ of concentrations and $1.05 \times 10^{-2}$ to $8.13 \times 10^{-2} \mathrm{mg} / \mathrm{g}$ of plant material between $D$. arachidna and D. hamiltonii (Table 2), following a peak area number in the extract chromatograms (Figure 2). The chromatogram of the methanol (solvent) and lidocaine standard, plotting the peak areas and the standard concentration to create a linear equation, $y=3241.5 x-7.23$ and the correlation coefficient $\left(R^{2}\right)$ at 0.99 , is shown in Figure 3.

\subsection{Toxicity}

\subsubsection{Cytotoxicity}

The maximum concentration of the hexane and ethanol extracts of the six Dioscorea species leaves were 10-fold diluted five times to make the working concentrations for the MTT assays on PBMCs. The results showed no toxicity on cellular levels, i.e., no $\mathrm{IC}_{50}$ values, with high cell viability percentages from $60.48 \pm 0.07 \%$ (D. bulbifera) to $99.49 \pm 0.14 \%$ (D. glabra). All details of the MTT results are shown in Figure 4 and Table 3. 
Table 2. Lidocaine measurement by GC compared to lidocaine standard resulting in concentration $(\mu \mathrm{g} / \mathrm{mL}, \mathrm{mg} / \mathrm{mL})$ and amount (mg/g plant).

\begin{tabular}{|c|c|c|c|c|c|c|}
\hline \multirow{3}{*}{ Plant Extract } & \multirow{3}{*}{ Retention Time (min) } & \multirow{3}{*}{$\begin{array}{c}\text { Peak Area } \\
\left(\mathrm{pA}^{*} \mathrm{~s}\right)\end{array}$} & \multicolumn{4}{|c|}{ Lidocaine } \\
\hline & & & \multicolumn{2}{|c|}{ Concentration } & \multicolumn{2}{|c|}{ Amount } \\
\hline & & & $\mu \mathrm{g} / \mathrm{mL}$ & $\mathrm{mg} / \mathrm{mL}$ & $\mathrm{mg} / \mathrm{g}$ & $\mathrm{mg} / 100 \mathrm{~g}$ \\
\hline Dioscorea alata & 5.87 & 47.55 & 16.90 & $16.90 \times 10^{-3}$ & $5.91 \times 10^{-2}$ & 5.92 \\
\hline D. arachidna & 5.87 & 5.18 & 3.83 & $3.83 \times 10^{-3}$ & $1.05 \times 10^{-2}$ & 1.05 \\
\hline D. brevipetiolata & 5.88 & 16.18 & 7.83 & $7.83 \times 10^{-3}$ & $2.03 \times 10^{-2}$ & 2.03 \\
\hline D. bulbifera & 5.87 & 14.58 & 6.73 & $6.73 \times 10^{-3}$ & $1.85 \times 10^{-2}$ & 1.85 \\
\hline D. decipiens & 5.87 & 21.69 & 8.92 & $8.92 \times 10^{-3}$ & $2.68 \times 10^{-2}$ & 2.68 \\
\hline D. depauperata & 5.88 & 29.73 & 11.40 & $11.40 \times 10^{-3}$ & $3.71 \times 10^{-2}$ & 3.71 \\
\hline D. esculenta & 5.87 & 20.59 & 8.58 & $8.58 \times 10^{-3}$ & $2.79 \times 10^{-2}$ & 2.79 \\
\hline D. glabra & 5.88 & 15.59 & 7.04 & $7.04 \times 10^{-3}$ & $2.46 \times 10^{-2}$ & 2.46 \\
\hline D. hamiltonii & 5.88 & 68.03 & 23.22 & $23.22 \times 10^{-3}$ & $8.13 \times 10^{-2}$ & 8.13 \\
\hline D. hispida & 5.88 & 14.75 & 6.78 & $6.78 \times 10^{-3}$ & $2.03 \times 10^{-2}$ & 2.03 \\
\hline D. pentaphylla & 5.88 & 11.94 & 5.91 & $5.91 \times 10^{-3}$ & $1.92 \times 10^{-2}$ & 1.92 \\
\hline
\end{tabular}

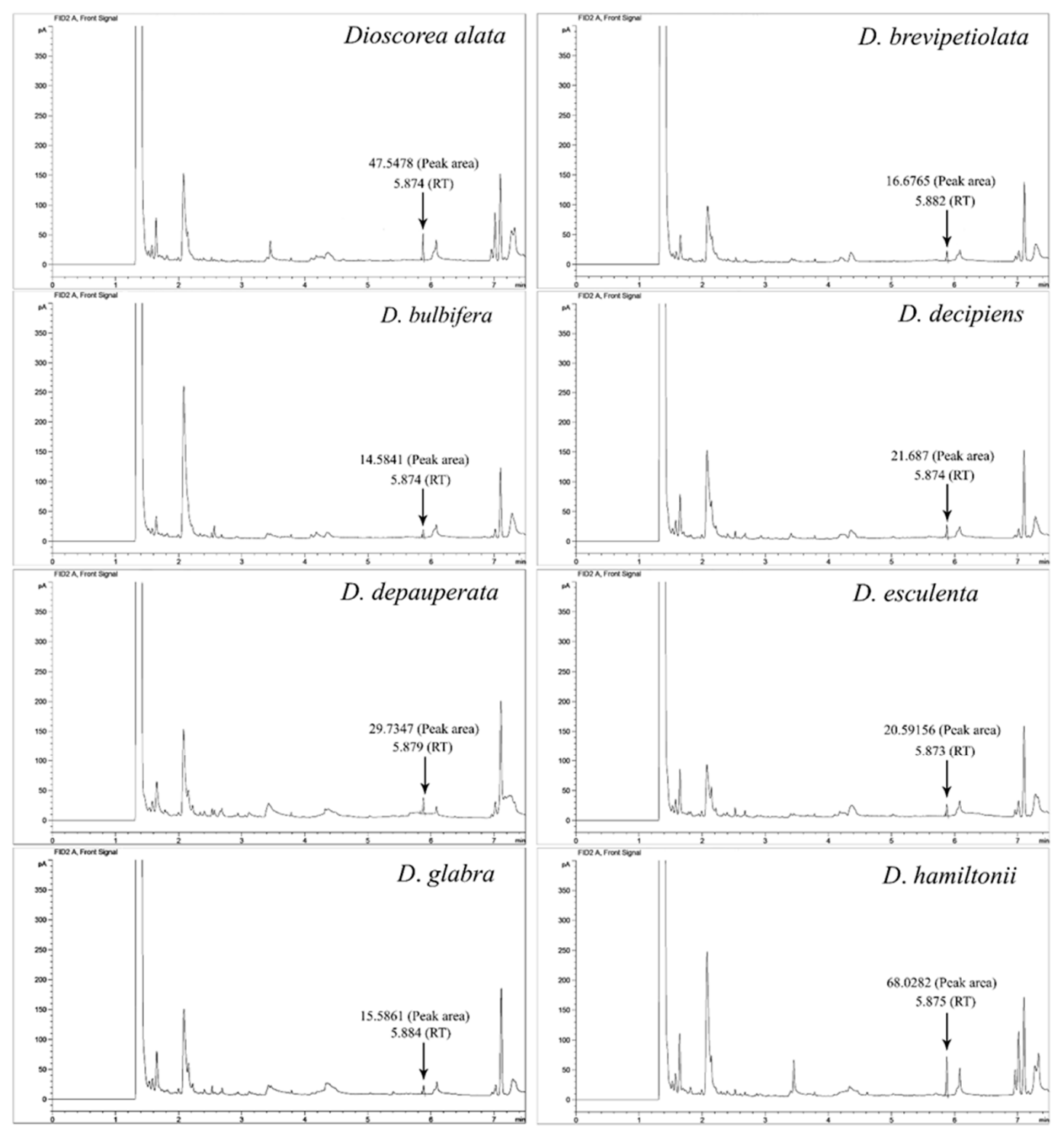

Figure 2. The representative peak area chromatograms of lidocaine from the eight of the 11 Dioscorea species studied, D. alata, D. brevipetiolata, D. bulbifera, D. decipiens, D. depauperata, D. esculenta, D. glabra and D. hamiltonii. 

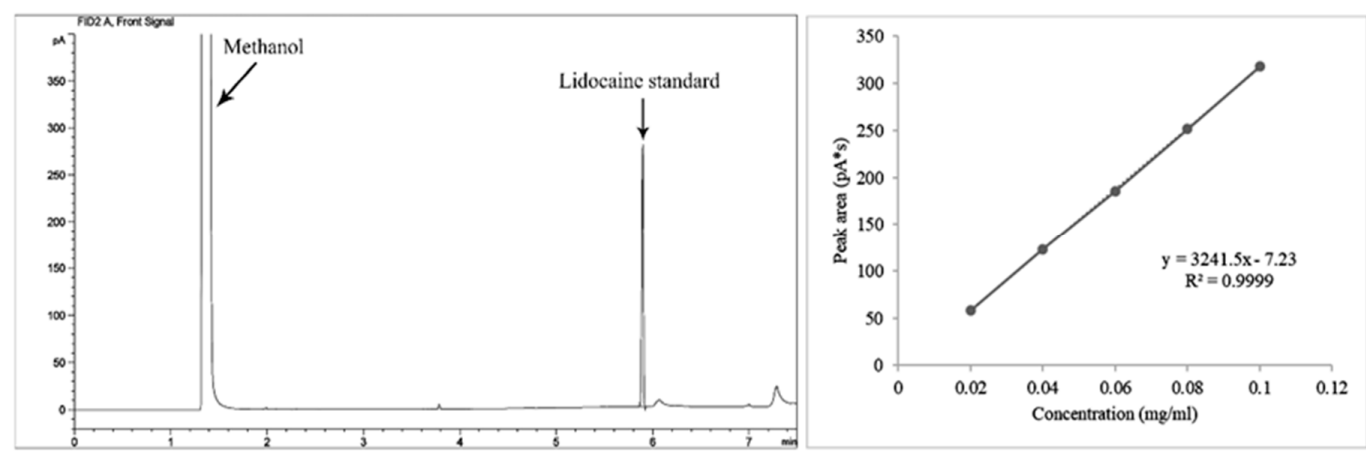

Figure 3. Chromatogram of the lidocaine standard and methanol solvent, and the graph of the peak area and the standard at $0.02,0.04,0.06,0.08$ and $0.10 \mathrm{mg} / \mathrm{mL}$ concentrations gave a correlation coefficient $\left(\mathrm{R}^{2}\right)$ at 0.99 and linear equation, $y=3241.5 x-7.23$, which was used for lidocaine content calculation of the plant extract.
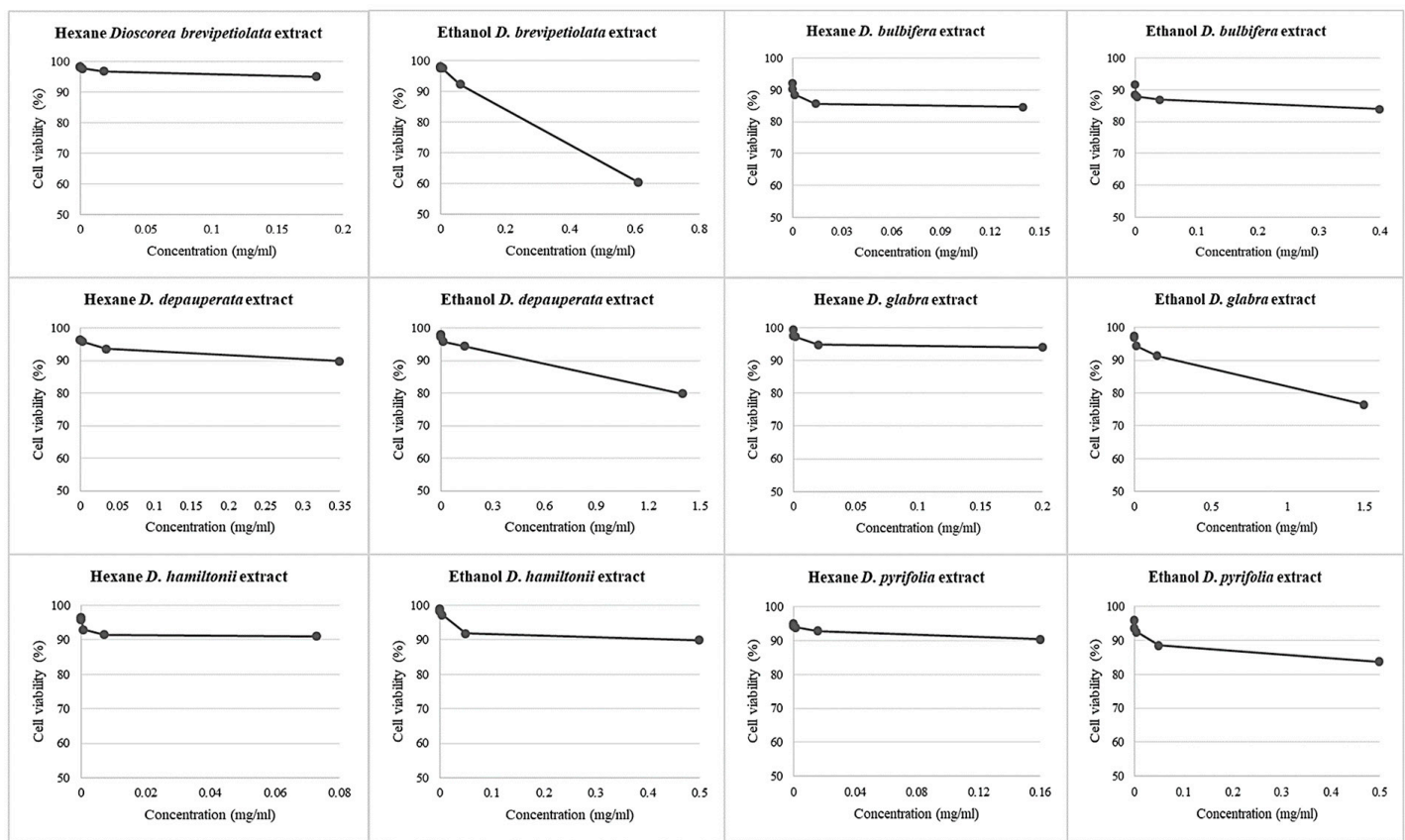

Figure 4. The plotting graph derived from the MTT assay, $\mathrm{PBMC}_{\mathrm{s}}$ treated with two extracts of six Dioscorea species: hexane and ethanol extracts at various concentrations.

Table 3. The result of the MTT assay showing viability percentage of $\mathrm{PBMC}_{\mathrm{s}}$ treated with hexane and ethanol extracts of six Dioscorea species with five working concentrations showing no toxicity, without $\mathrm{IC}_{50}$ values and high cell variability percentages.

\begin{tabular}{clccc}
\hline \multirow{2}{*}{ Plant Extract } & Solvent & $\begin{array}{c}\text { Maximum Concentration } \\
(\mathbf{m g} / \mathbf{m L})\end{array}$ & $\begin{array}{c}\text { Working Concentration } \\
(\mathbf{m g} / \mathbf{m L})\end{array}$ & Cell Viability (\%) \pm S.D. \\
\hline \multirow{2}{*}{ D. brevipetiolata } & hexane & 1.81 & $0.18-0.18 \times 10^{-4}$ & $95.09 \pm 0.04-98.37 \pm 0.03$ \\
& ethanol & 6.15 & $0.61-0.61 \times 10^{-4}$ & $60.48 \pm 0.07-98.21 \pm 0.04$ \\
\hline \multirow{2}{*}{ D. bulbifera } & hexane & 1.46 & $0.14-0.14 \times 10^{-4}$ & $84.62 \pm 0.13-92.18 \pm 0.16$ \\
& ethanol & 4.00 & $0.40-0.40 \times 10^{-4}$ & $84.01 \pm 0.10-91.65 \pm 0.14$ \\
\hline \multirow{2}{*}{ D. depauperata } & hexane & 3.53 & $0.35-0.35 \times 10^{-4}$ & $89.87 \pm 0.07-96.40 \pm 0.10$ \\
& ethanol & 14.21 & $1.42-1.42 \times 10^{-4}$ & $79.86 \pm 0.10-97.23 \pm 0.08$ \\
\hline \multirow{2}{*}{ D. glabra } & hexane & 2.00 & $0.20-0.20 \times 10^{-4}$ & $94.03 \pm 0.07-99.49 \pm 0.14$ \\
& ethanol & 15.30 & $1.53-1.53 \times 10^{-4}$ & $76.52 \pm 0.09-97.30 \pm 0.10$ \\
\hline \multirow{2}{*}{ D. hamiltonii } & hexane & 0.73 & $0.07-0.07 \times 10^{-4}$ & $91.03 \pm 0.06-96.45 \pm 0.12$ \\
& ethanol & 5.00 & $0.50-0.50 \times 10^{-4}$ & $89.90 \pm 0.09-98.93 \pm 0.09$ \\
\hline \multirow{2}{*}{ D. pyrifolia } & hexane & 1.66 & $0.16-0.16 \times 10^{-4}$ & $90.36 \pm 0.10-95.02 \pm 0.12$ \\
& ethanol & 5.00 & $0.50-0.50 \times 10^{-4}$ & $83.77 \pm 0.08-96.04 \pm 0.13$ \\
\hline
\end{tabular}




\subsubsection{Genotoxicity}

In-depth toxicity testing by comet assay with the highest working concentration which lacked $\mathrm{IC}_{50}$ values indicated that the six hexane extracts did not induce DNA damage. Ethanol extracts of three species, D. brevipetiolata, D. hamiltonii and D. pyrifolia, induced significant $(p<0.01)$ DNA damage compared to the negative control (untreated cells), and ethanol extracts of the last two species, $D$. depauperata and D. glabra, violently broke DNA in pieces such that the tail length cannot be measured, noting that these two ethanol D. depauperata and D. glabra extracts had higher concentrations than the other four study species, with the similar weight at $20 \mathrm{~g}$ in $100 \mathrm{~mL}$ solvent. The ethanol extract of the last species, D. bulbifera, did not induce DNA damage (Figure 5 and Table 4).
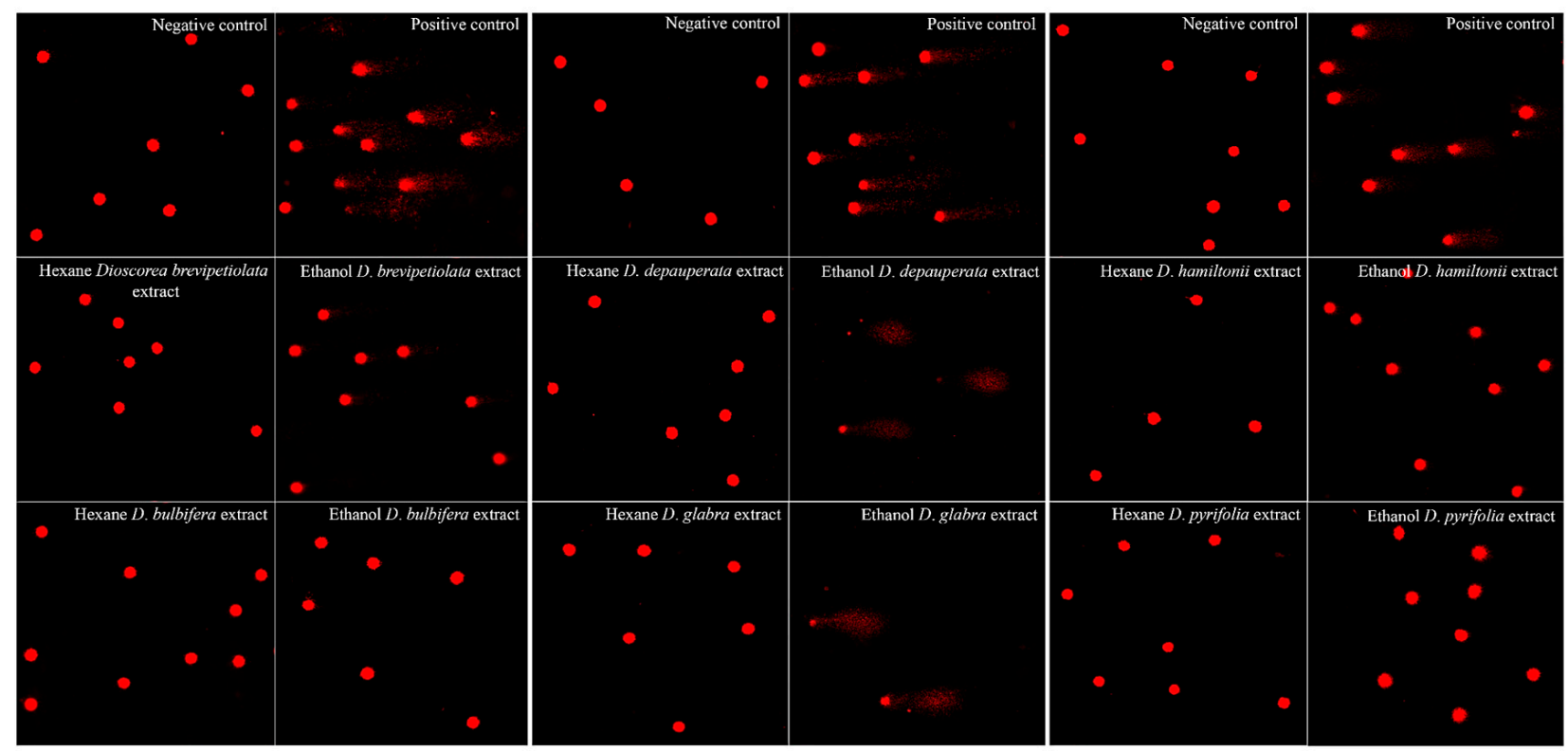

Figure 5. The comet assay images $(200 \times)$ of $\mathrm{PBMC}_{\mathrm{s}}$ treated with the highest working concentrations of the hexane and ethanol of six Dioscorea species extracts compared to the negative control, found from the images to have no DNA damage (all six species of hexane extracts), significant DNA damage compared to the negative control (D. brevipetiolata, D. hamiltonii and D. pyrifolia), DNA damage in pieces (D. depauperata and D. glabra extracts), and no DNA damage (D. bulbifera).

Table 4. The result of the comet assay showing the median and standard deviation of olive tail moment values of PBMC after treatment with the hexane and ethanol extracts of six Dioscorea species compared to the negative control. They showed no DNA damage (all six species of hexane extracts), significant DNA damage compared to the negative control (D. brevipetiolata, D. hamiltonii and D. pyrifolia), DNA damage in pieces (D. depauperata and D. glabra extracts), and no DNA damage (D. bulbifera).

\begin{tabular}{|c|c|c|c|c|}
\hline Plant & Solvent & Median \pm S.D. of Negative Control & Median \pm S.D. of Treated Cell & $p$ Value \\
\hline $\begin{array}{c}\text { D. brevipetiolata } \\
\text { D. bulbifera }\end{array}$ & $\begin{array}{l}\text { hexane } \\
\text { ethanol } \\
\text { hexane } \\
\text { ethanol }\end{array}$ & $0.17 \pm 0.02 \times 10^{-2}$ & $\begin{array}{c}0.49 \pm 0.01 \times 10^{-2} \\
131.83 \pm 0.19 \times 10^{-2} \\
0.18 \pm 0.07 \times 10^{-2} \\
0.55 \pm 0.02 \times 10^{-2}\end{array}$ & $\begin{array}{l}>0.05 \\
<0.05 \\
>0.05 \\
>0.05\end{array}$ \\
\hline $\begin{array}{c}\text { D. depauperata } \\
\text { D. glabra }\end{array}$ & $\begin{array}{l}\text { hexane } \\
\text { ethanol } \\
\text { hexane } \\
\text { ethanol }\end{array}$ & $0.14 \pm 0.02 \times 10^{-2}$ & $\begin{array}{c}0.14 \pm 0.02 \times 10^{-2} \\
\text { N/A * } \\
0.14 \pm 0.01 \times 10^{-2} \\
\text { N/A* }\end{array}$ & $\begin{array}{l}>0.05 \\
\mathrm{~N} / \mathrm{A}^{*} \\
>0.05 \\
\mathrm{~N} / \mathrm{A}^{*}\end{array}$ \\
\hline $\begin{array}{l}\text { D. hamiltonii } \\
\text { D. pyrifolia }\end{array}$ & $\begin{array}{l}\text { hexane } \\
\text { ethanol } \\
\text { hexane } \\
\text { ethanol }\end{array}$ & $0.07 \pm 0.02 \times 10^{-2}$ & $\begin{array}{c}0.07 \pm 0.01 \times 10^{-2} \\
69.07 \pm 0.18 \times 10^{-2} \\
0.07 \pm 0.08 \times 10^{-2} \\
0.17 \pm 0.02 \times 10^{-2}\end{array}$ & $\begin{array}{l}>0.05 \\
<0.05 \\
>0.05 \\
<0.05\end{array}$ \\
\hline
\end{tabular}

* Not available. 


\subsection{Biological Activity}

Following this, these two concentrations, the ethanol D. depauperata and D. glabra extracts, were selected for further biological activity testing on the two cancer cell lines, HepG2 and HCT-116 compared to the cisplatin control, and insecticidal efficiency. The results showed the ethanol extract of D. depauperata and D. glabra toxicity on HepG2 with $\mathrm{IC}_{50}$ values at $1.32 \mathrm{mg} / \mathrm{mL} / 24 \mathrm{~h}$ and $1.30 \mathrm{mg} / \mathrm{mL} / 48 \mathrm{~h}$, no effects on HCT-116, and cisplatin toxicity on both HepG2 and HCT-116 at an $\mathrm{IC}_{50}$ value of $0.095 \mathrm{mg} / \mathrm{mL} / 24 \mathrm{~h}$ and $0.29 \mathrm{mg} / \mathrm{mL} / 48 \mathrm{~h}$ (Figure 6 and Table 5).

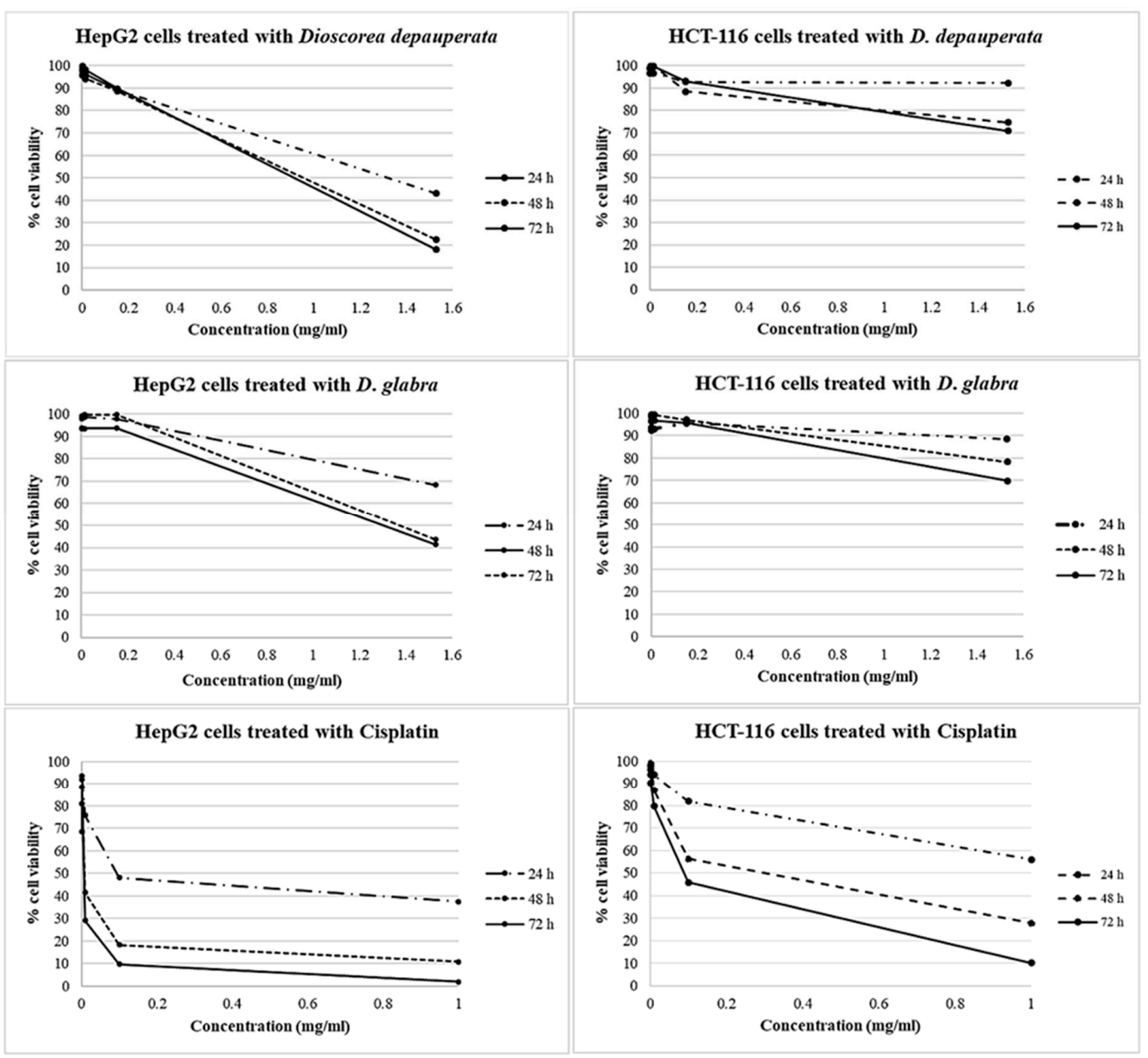

Figure 6. The cytotoxicity graphs showing cell viability percentages of HepG2 and HCT-116 cell lines treated with Dioscorea depauperata, D. glabra extracts and cisplatin at various concentrations and timings.

Table 5. The viability percentages of HepG2 and HCT-116 cell lines treated with Dioscorea depauperata, D. glabra extracts and cisplatin at various concentrations and timings.

\begin{tabular}{|c|c|c|c|c|c|c|}
\hline \multirow{2}{*}{ Sample } & \multirow{2}{*}{$\begin{array}{c}\text { Time of Treated } \\
\text { (Hours) }\end{array}$} & \multirow{2}{*}{$\begin{array}{c}\text { Working } \\
\text { Concentration } \\
(\mathrm{mg} / \mathrm{mL})\end{array}$} & \multicolumn{2}{|c|}{ Cell Viability (\% \pm S.D.) } & \multicolumn{2}{|c|}{$\mathrm{IC}_{50}$ Value $(\mathrm{mg} / \mathrm{mL}) /$ Time (Hours) } \\
\hline & & & HepG2 Cell Line & HCT-116 Cell Line & HepG2 Cell Line & HCT-116 Cell Line \\
\hline \multirow{3}{*}{$\begin{array}{l}\text { D. depauperata } \\
\text { (Ethanol extract) }\end{array}$} & 24 & \multirow{3}{*}{$1.53 \times 10^{-4}-1.53$} & $95.91-42.92 \pm 0.07-0.07$ & $96.74-92.36 \pm 0.08-0.06$ & \multirow{3}{*}{$1.32 / 24$} & \multirow{3}{*}{-} \\
\hline & 48 & & $99.70-22.36 \pm 0.06-0.06$ & $98.97-74.60 \pm 0.08-0.10$ & & \\
\hline & 72 & & $97.97-18.01 \pm 0.05-0.04$ & $98.77-70.88 \pm 0.07-0.08$ & & \\
\hline \multirow{3}{*}{$\begin{array}{c}\text { D. glabra } \\
\text { (Ethanol extract) }\end{array}$} & 24 & \multirow{3}{*}{$1.53 \times 10^{-4}-1.53$} & $98.38-68.27 \pm 0.07-0.01$ & $92.51-88.47 \pm 0.08-0.07$ & \multirow{3}{*}{$1.30 / 48$} & \multirow{3}{*}{-} \\
\hline & 48 & & $93.93-41.35 \pm 0.07-0.08$ & $96.56-78.28 \pm 0.06-0.06$ & & \\
\hline & 72 & & $98.03-43.58 \pm 0.06-0.06$ & $98.42-69.79 \pm 0.05-0.09$ & & \\
\hline \multirow{3}{*}{ Cisplatin } & 24 & \multirow{3}{*}{$1.00 \times 10^{-4}-1.00$} & $96.32-36.75 \pm 0.10-0.06$ & $97.81-55.92 \pm 0.07-0.04$ & \multirow{3}{*}{$0.09 / 24$} & \multirow{3}{*}{$0.29 / 48$} \\
\hline & 48 & & $84.07-10.20 \pm 0.08-0.01$ & $98.96-27.67 \pm 0.08-0.02$ & & \\
\hline & 72 & & $81.81-2.17 \pm 0.07-0.01$ & $93.89-10.05 \pm 0.07-0.02$ & & \\
\hline
\end{tabular}


Further, in the comet assay, these $\mathrm{IC}_{50}$ values of the two ethanol extracts applied to HepG2 and HCT-116 cell lines, significantly presented DNA damaged $(p<0.01)$ compared to the negative controls (the two untreated cell lines) (Figure 7 and Table 6).
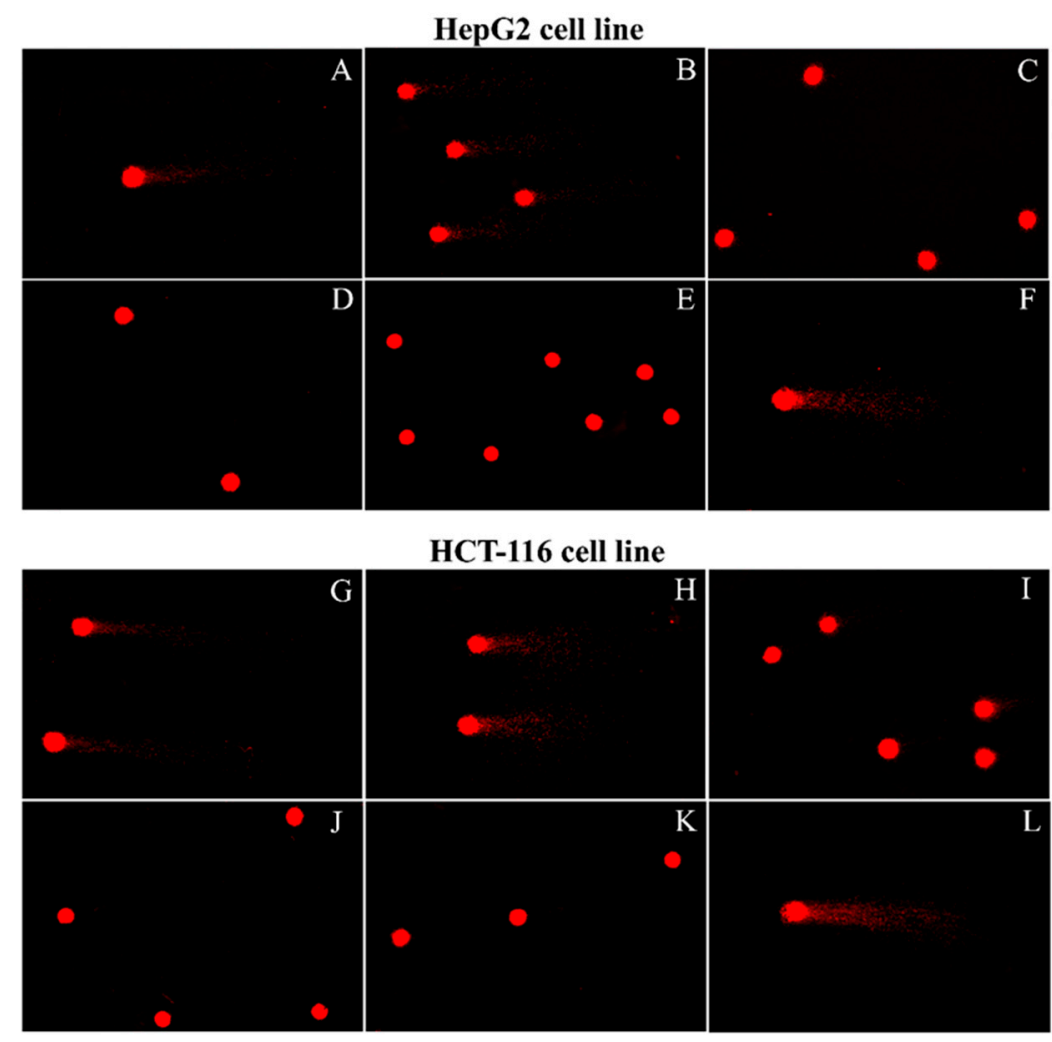

Figure 7. The comet assay images $(200 \times)$ of HepG2 and HCT-116 cell lines treated with ethanol Dioscorea depauperata, D. glabra extracts and cisplatin: HepG2 cells (A) treated with D. depauperata for $24 \mathrm{~h}$, (B) treated with D. glabra for $48 \mathrm{~h}$, (C) treated with cisplatin for $24 \mathrm{~h}$, (D) negative control for $24 \mathrm{~h},(\mathrm{E})$ negative control for $48 \mathrm{~h}$, (F) positive control; HCT-116 cells (G) treated with $D$. depauperata for $72 \mathrm{~h}$, (H) treated with D. glabra for $72 \mathrm{~h}$, (I) treated with cisplatin for $48 \mathrm{~h}$, (J) negative control for $48 \mathrm{~h},(\mathbf{K})$ negative control for $72 \mathrm{~h}$, and $(\mathbf{L})$ positive control.

Table 6. Comet assay of HepG2 and HCT-116 cell lines showing the median and standard deviation of olive tail moment values after treatment with Dioscorea depauperata, D. glabra extracts and cisplatin at various concentrations and timings compared to the negative control.

\begin{tabular}{|c|c|c|c|c|c|c|}
\hline \multirow{2}{*}{ Sample } & \multirow{2}{*}{ Treated Cell Type } & \multirow{2}{*}{$\begin{array}{l}\text { Concentration of } \\
\text { Samples }(\mathrm{mg} / \mathrm{mL})\end{array}$} & \multirow{2}{*}{$\begin{array}{l}\text { Time of Treated } \\
\text { (Hours) }\end{array}$} & \multicolumn{2}{|c|}{ OTM (Median \pm S.D.) } & \multirow{2}{*}{$\begin{array}{c}p \text { Value of } \\
\text { Treated Cell }\end{array}$} \\
\hline & & & & Negative Control & Treated Cell & \\
\hline \multirow{2}{*}{ D. depauperata } & HepG2 & 1.32 & 24 & $370.00 \pm 3.60 \times 10^{-4}$ & $4.021 \pm 1.57$ & $<0.01$ \\
\hline & HCT-116 & 1.53 & 72 & $6.53 \pm 0.22 \times 10^{-4}$ & $9.050 \pm 2.55$ & $<0.01$ \\
\hline \multirow{2}{*}{ D. glabra } & HepG2 & 1.30 & 48 & $230.00 \pm 3.20 \times 10^{-4}$ & $12.743 \pm 2.39$ & $<0.01$ \\
\hline & HCT-116 & 1.53 & 72 & $6.53 \pm 0.22 \times 10^{-4}$ & $11.942 \pm 3.05$ & $<0.01$ \\
\hline \multirow{2}{*}{ cisplatin } & HepG2 & 0.09 & 24 & $370.00 \pm 3.60 \times 10^{-4}$ & $0.703 \pm 0.19$ & $<0.01$ \\
\hline & HCT-116 & 0.29 & 48 & $6.28 \pm 0.54 \times 10^{-4}$ & $0.447 \pm 0.21$ & $<0.01$ \\
\hline
\end{tabular}

\subsection{Pesticidal Efficiency}

When the 25 day-old $B$. chinensis pots (Figure 8 ) were transferred to the field and finished the experiment at 60 days old (Figure 9), the B. chinensis individuals which were destroyed by pests in an experiment (the controls A, B, and the experimental samples $\mathrm{C}$ and $\mathrm{D})$ were counted and scored with the following results: all of the $B$. chinensis individuals of the control A, 26 of the control B, 10 of the sample C and 4 of the sample D 
were destroyed, scored as 30,26, 10 and 4 . All details on both destroyed individuals and characters of B. chinensis are shown in Figure 10 and Table 7.

A

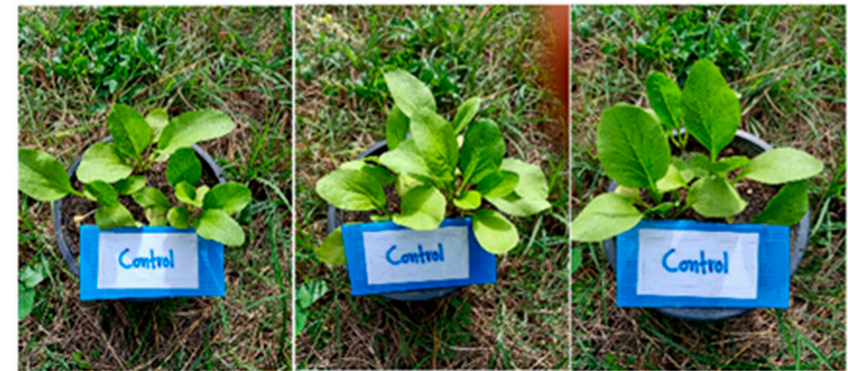

$\mathrm{C}$
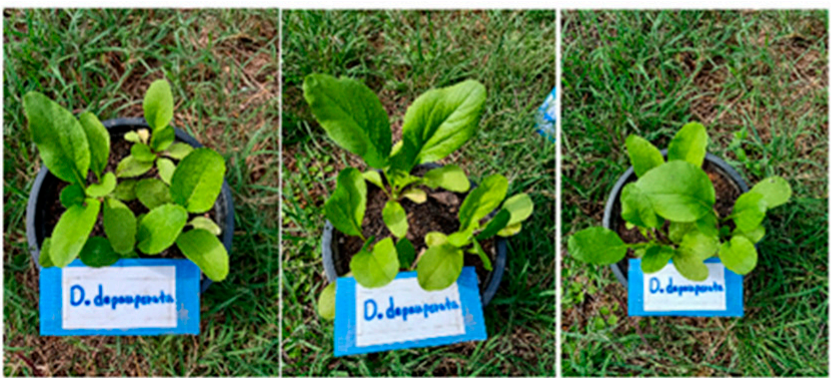

B

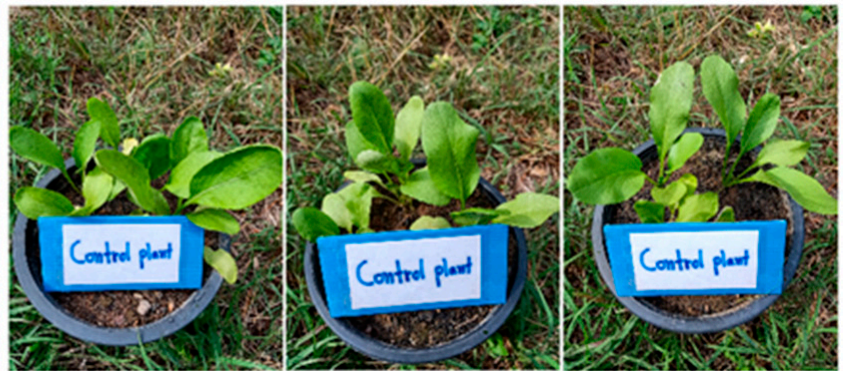

D
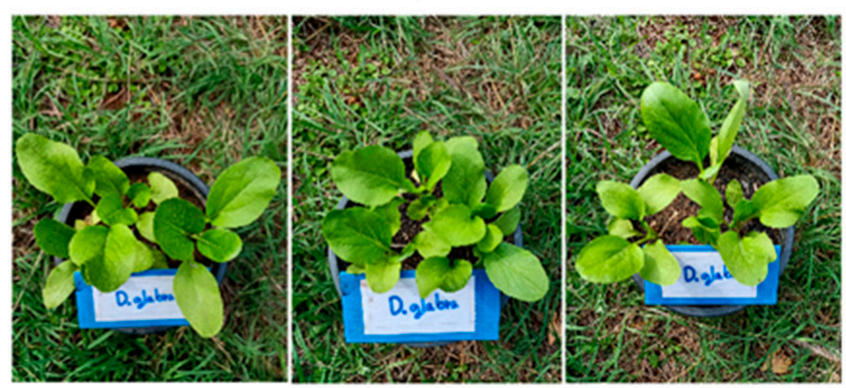

Figure 8. Comparison of 25-day-old Brassica chinenesis which were moved from the nursery to the field and sprayed with the control A (extract-untreated Brassica chinensis) in (A), control B (Dioscorea bulbifera extract) in (B), the sample C (D. depauperata extract) in (C), and sample D (D. glabra extract) in (D).

A

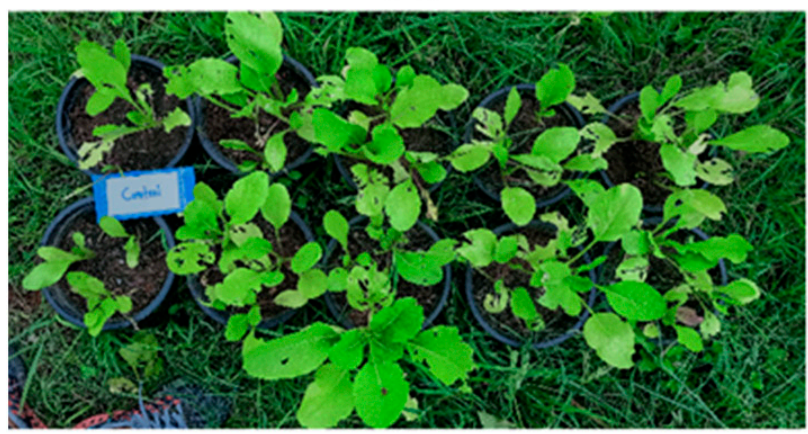

$\mathrm{C}$

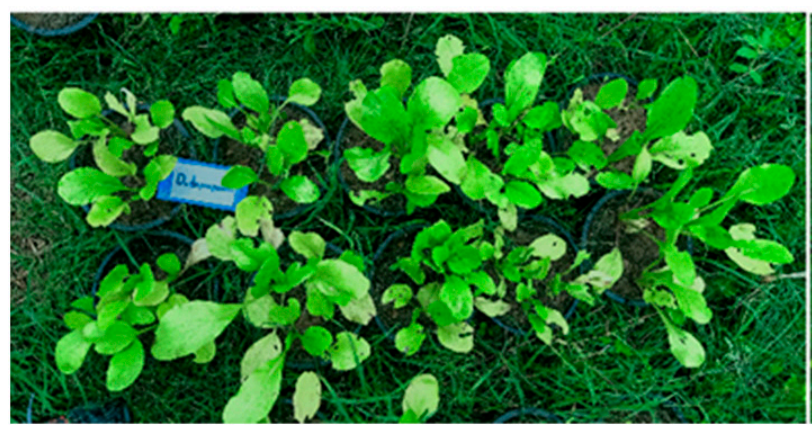

$\mathrm{B}$

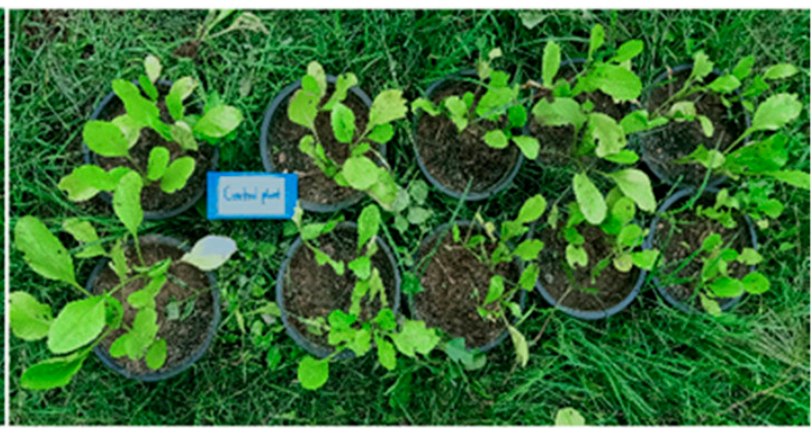

$\mathrm{D}$

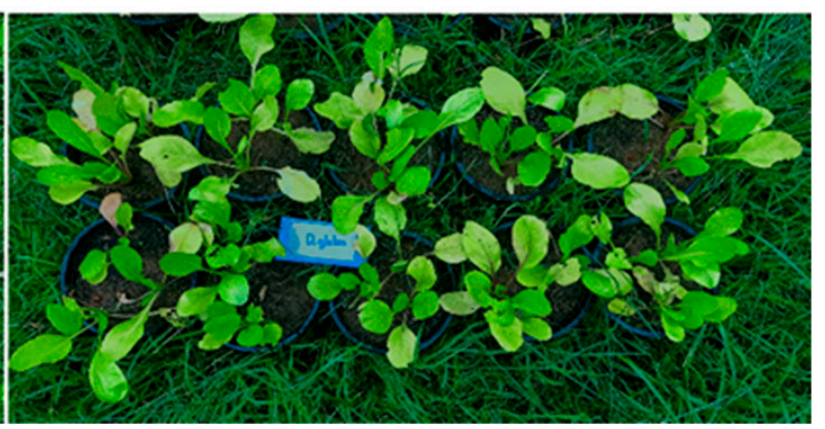

Figure 9. Comparison of 60-day-old Brassica chinenesis after the completed experiment showing the destroyed individual scoring; B. chinenesis was sprayed with the control A (extract-untreated Brassica chinensis) in (A), control B (Dioscorea bulbifera extract) in (B), the sample C (D. depauperata extract) in (C), and sample D (D. glabra extract) in (D). 


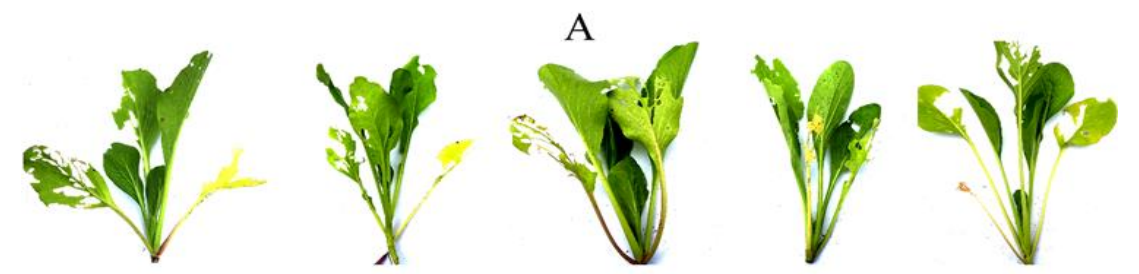

B
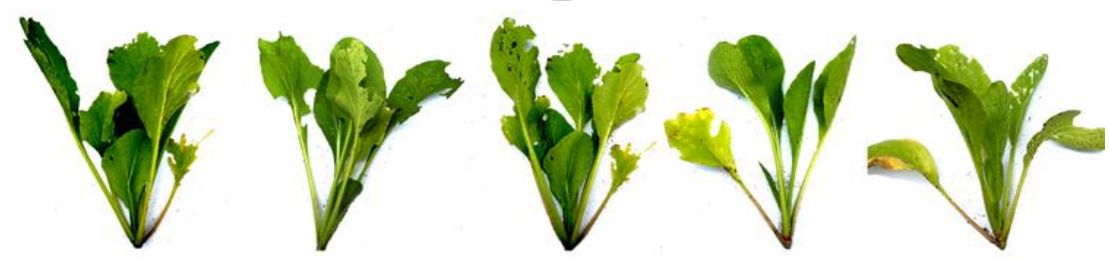

$\mathrm{C}$
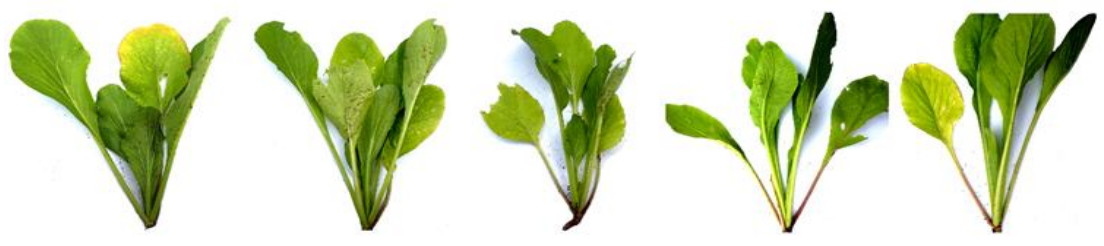

$\mathrm{D}$

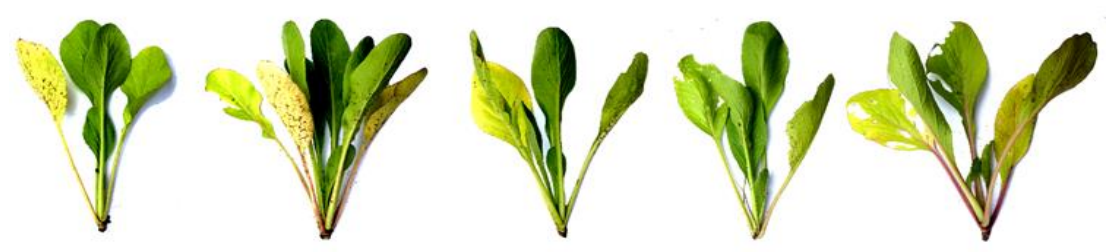

Figure 10. The characteristics of destroyed Brassica chinensis after 60 days of treatment comparing between the control extract-untreated plants (A), the plants treated with the extracts from Dioscorea bulbifera (B), D. depauperata (C), and D. glabra (D).

Table 7. The results of pesticidal efficiency including four experiments (control A, B and sample C, D), where each experiment comprised 10 pots, each pot comprised 3 individuals, the individuals were scored as 1, 2, 3 when they were destroyed/bitten by a pest, 0 as if no individual was destroyed. Control A = extract-untreated Brassica chinensis, B. chinensis treated with extracts from Dioscorea bulbifera (Control B), sample C = D. depauperata (sample C), and D. glabra (sample D).

\begin{tabular}{cccccccccccc}
\hline \multirow{2}{*}{ Experiment } & \multicolumn{8}{c}{ Number of Destroyed Brassica chinensis Individuals in a Pot } \\
\cline { 2 - 12 } & Pot 1 & Pot 2 & Pot 3 & Pot 4 & Pot 5 & Pot 6 & Pot 7 & Pot 8 & Pot 9 & Pot 10 & Total \\
\hline Control A & 3 & 3 & 3 & 3 & 3 & 3 & 3 & 3 & 3 & 3 & 30 \\
Control B & 1 & 3 & 3 & 3 & 3 & 3 & 3 & 2 & 3 & 2 & 26 \\
Sample C & 1 & 1 & 0 & 1 & 1 & 2 & 1 & 1 & 1 & 1 & 10 \\
Sample D & 1 & 0 & 0 & 1 & 1 & 0 & 0 & 0 & 0 & 1 \\
\hline
\end{tabular}

\section{Discussion}

This is interesting research with new findings including lidocaine content, a unique substance expected to be part of the genus Dioscorea's characteristics, and that $D$. depauaperata and D. glabra species can be natural pesticides and lead to anticancer drug development. Lidocaine was firstly found by GC-MS analysis in D. depauperata and D. glabra of the six studied species. The substance is very important worldwide, being used as an anesthetic in medical treatment in small amounts; quoted as an origin of modern local anesthetics [9]; broadly used in various therapeutic approaches for different types of pain, such as visceral/central pain, renal colic, and in the emergency department, since it has antinociceptive properties, turning it into a medication that is safe to administer via different routes, 
making it available for use in a variety of medical conditions [10]. The $10 \%(0.1 \mathrm{~g} / \mathrm{mL})$ lidocaine sprayed at both the oropharyngolarynx and tracheal tube cuff has a superior effect in attenuation of hemodynamic response to laryngoscopy and intubation [11]. Patients with myofascial pain in the neck and upper back are treated with a $1 \%(0.01 \mathrm{~g} / \mathrm{mL})$ lidocaine trigger point injection [12]. So, the discovery of lidocaine in plants should be an alternative or be used as a substitute that is both naturally sourced and is more economical than synthetics. Given this, more Dioscorea species, included 11 species, D. alata, D. arachidna, D. brevipetiolata, D. bulbifera, D. decipiens, D. depauperata, D. esculenta, D. glabra, D. hamiltonii, $D$. hispida and D. pentaphylla were collected for the lidocaine measurement by GC compared to the lidocaine standard, and the substance was shown in all the 11 studied species. From the larger number of species that have been studied, it can be concluded that lidocaine is a unique substance in the genus Dioscorea, benefitting plant systematics. Additionally, each of the species may be useful for natural product creation following previously mentioned properties - for example, ointments to relieve pain. If there was a prototype and clinical trial, it would be of great benefit to mankind. One more piece of interesting information derived from the research is that, from the two studied species, D. depuaperata and D. glabra have a selective property of being toxic to the HepG2 cancer cell line, but no toxicity to human cells compared to cisplatin activity which is an anti-cancer chemical, even though both Dioscorea had less anti-cancer activity than cisplatin. This result agrees with previous data reporting on substances derived from some Dioscorea species which have anticancer activity [3,6]. These two species with anti-cancer compounds should be experimented on in depth with a clinical trial for the further advances in cancer treatment. Additionally, the two species may be applied as an alternative pesticide for the field or garden, without hazardous effects on humans, as they have high efficiency as an insect repellent. The application method is easier than that with other plants, such as neem, which have to be fermented, whereas these two plants are simply ground, mixed with water, and then used.

Traditionally, several Dioscorea species have been used for the various activities mentioned in the introduction, but from the tuber or bulbil. Here, the research experimented on their leaves, which is a sustainable use of natural resources, because the leaves can always regrow.

\section{Materials and Methods}

\subsection{Chemicals and Cell Lines}

Absolute ethanol and n-Hexane AR grade were purchased from ANaPURE (New Zealand). Methanol HPLC grade, ethanol HPLC grade and dimethyl sulfoxide (DMSO) AR grade were purchased from Fisher (Loughborough, Leicestershire, UK). Lidocaine standard and 3-(4,5-dimethylthiazol-2-yl)-2,5-diphenyltetrazolium bromide (MTT) were purchased from Sigma-Aldrich (Burlington, MA, USA). RPMI 1640, with L-glutamine, Dulbecco's Modified Eagle medium low glucose (DMEM), penicillin and trypsin were purchased from Capricorn Scientific GmbH (Ebsdorfergrund, Hesse, Germany). Ficoll-Paque Plus was purchased from GE Healthcare (Marlborough, MA, USA). Fetal bovine serum was purchased from HyClone (Marlborough, MA, USA). Hepatocellular carcinoma cell line (HepG2) and colorectal carcinoma cell line (HCT-116) were purchased from American type culture collection (ATCC, Manassas, VA, USA). Cisplatin was purchased from Fresenius Kabi (Lake Zurich, IL, USA).

\subsection{Plant Materials and Extract Preparation}

The mature leaves of the six Dioscorea species included D. brevipetiolata Prain and Burkill, D. bulbifera L., D. depauperata Prain and Burkill, D. glabra Roxb., D. pyrifolia Kunth and D. hamiltonii Hook.f. were collected in wild areas in Udon Thani province, northeastern Thailand (and D. alata L., D. arachidna Prain and Burkill, D. decipiens Hook.f., D. esculenta (Lour.) Burkill, D. hispida Dennst. and D. pentaphylla L. were also collected later for lidocaine detection only). They were identified following the Flora of Thailand, 2009, Dioscoreaceae. The leaves were rinsed, air-dried at room temperature for 2-3 days, 
then they were ground into a powder. The powder was combined with hexane or ethanol, separately at a rate 1:5, and soaked for $72 \mathrm{~h}$. Each solution was filtered through a Whatman no. 1 filter paper. The filtrates were kept at $-20{ }^{\circ} \mathrm{C}$ until being used in experiments including phytochemical component analysis by gas chromatography-mass spectrometry (GC-MS), 3-(4,5-dimethylthiazol-2-yl)-2,5-diphenyltetrazolium bromide (MTT), comet assays, and anticancer testing on hepatocellular carcinoma (HepG2) and colorectal carcinoma (HCT-116) cell lines.

\subsection{Gas Chromatography-Mass Spectrometry (GC-MS)}

The analysis was performed using an Agilent Technologies GC 6890 N/5973 inert mass spectrometer fused with a capillary column $(30.0 \mathrm{~m} \times 250 \mu \mathrm{m} \times 0.25 \mu \mathrm{m})$. Helium gas was used as the carrier at a constant flow rate of $1 \mathrm{~mL} / \mathrm{min}$. The injection and masstransferred line temperature was set at $280^{\circ} \mathrm{C}$. The oven temperature was programmed for $70{ }^{\circ} \mathrm{C}$ to $120^{\circ} \mathrm{C}$ at $3{ }^{\circ} \mathrm{C} / \mathrm{min}$, held isothermally for $2 \mathrm{~min}$, and then raised to $270{ }^{\circ} \mathrm{C}$ at $5^{\circ} \mathrm{C} / \mathrm{min}$. A $1 \mu \mathrm{L}$ aliquot of the extract was injected in split mode. The relative percentage of the extract constituents was expressed as a percentage using peak area normalization. Component identification was determined by comparing the obtained mass spectra with the reference compounds in the Wiley 7N.1 library. 2.4.

\subsection{Lidocaine Detection by Gas-Chromatography Compared to the Lidocaine Standard}

Actually, lidocaine was measured in the six studied species. To be more reliable in systematics, lidocaine was measured in the extended number as 11 species. The $2 \mathrm{~g}$ sample leaves of the 11 studied species, D. alata, D. arachidna, D. brevipetiolata, D. bulbifera, D. decipiens, D. depauperata, D. esculenta, D. glabra, D. hamiltonii, D. hispida and D. pentaphylla was extracted with $10 \mathrm{~mL}$ methanol solvent, kept at room temperature, avoiding sunlight for $72 \mathrm{~h}$. The mixtures were filtered through Whatman no.1 filter paper (125 mm diameter), then each extract was used for lidocaine detection. The chromatographic conditions were: the GC used was performed with an Agilent Technologies GC7890B, equipped with flame ionization detector (FID) and HP-5 capillary column $(30.0 \mathrm{~m} \times 320 \mu \mathrm{m}$ i.d. $\times 0.25 \mu \mathrm{m}$ film thickness). Helium was used as a carrier gas with a flow rate of $1.6 \mathrm{~mL} / \mathrm{min}$. The injector and detector temperatures were $260^{\circ} \mathrm{C}$. The oven temperature was programed at an initial temperature of $120^{\circ} \mathrm{C}$, held for $2 \mathrm{~min}$, ramp rate of $20^{\circ} \mathrm{C} / \mathrm{min}$ and final temperature at $230^{\circ} \mathrm{C}$. The $1 \mu \mathrm{L}$ of each sample was injected to a column at split ratio 10:1.

Preparation of the lidocaine standard: the working solution of the standard at 20, 40, 60, 80 and $100 \mu \mathrm{g} / \mathrm{mL}$ was prepared in methanol. The lidocaine standard at various concentrations was injected for plotting the calibration curve. The linear equation and correlation coefficient were calculated by Microsoft Excel.

\subsection{Cytotoxicity and Genotoxicity Testing via MTT and Comet Assays}

The steps are as follows:

1. Stock Extract Preparation The solvents of the filtrates (from plant extract preparations) were removed with a rotary evaporator (Rotavapor R-210, Buchi, Switzerland) at 800-1000 mbar, $15^{\circ} \mathrm{C}$, and $600 \mathrm{rpm}$ for $2 \mathrm{~h}$. Then, dimethyl sulfoxide (DMSO) was added to the extracts until being completely dissolved and maintained as stock extracts at $-20^{\circ} \mathrm{C}$ conducting for the cytotoxicity and genotoxicity experiments.

2. Human Peripheral Blood Mononuclear Cells (PBMCs) Preparation PBMCs were isolated from sodium heparin anticoagulated venous blood from a blood bank using Ficoll-Paque Plus (GE Healthcare). Freshly isolated PBMCs with viability of at least $98 \%$ were used for the toxicity testing. The cells were suspended at a concentration of $1 \times 10^{6}$ cells $/ \mathrm{mL}$ for MTT and $0.4-0.6 \times 10^{6}$ cells $/ \mathrm{mL}$ for the comet assay in modified RPMI-1640 medium supplemented with 10\% FBS, 1\% antibiotic (streptomycin and penicillin).

3. MTT Assay The stock extract concentrations were serially 10-fold diluted with water, five times for the working concentrations. The prepared cells were seeded in 96-well 
plates, $125 \mu \mathrm{L}$ per well, and $12.5 \mu \mathrm{L}$ of the extract working concentrations were added to the corresponding wells, incubated for $24 \mathrm{~h}$ for PBMCs and 24, 48 and $72 \mathrm{~h}$ for cancer cell lines in a humidified $\mathrm{CO}_{2}$ incubator at $37^{\circ} \mathrm{C}$ and $5 \% \mathrm{CO}_{2}$. Corresponding DMSO concentrations were similarly prepared as vehicle controls, untreated cells and hydrogen peroxide-treated cells were the negative and positive controls, respectively. When the time was over, the plates were centrifuged at $1500 \mathrm{rpm}$ for $10 \mathrm{~min}$ and the medium was removed, the MTT (Sigma, USA) was added to a final concentration of $0.5 \mathrm{mg} / \mathrm{mL}$, the plates were wrapped with aluminum foil and incubated for $4 \mathrm{~h}$ at $37^{\circ} \mathrm{C}$. The formazan crystals were solubilized by adding $100 \mu \mathrm{L}$ DMSO to each well, and the plates were left in the dark for $2-4 \mathrm{~h}$. The absorbance was read at $570 \mathrm{~nm}$ with a microtiter plate spectrophotometer (Multifunction microplate reader; Varioskan Flash, Thermo fisher, Waltham, MA, USA). Wells containing medium and MTT without cells were used as blanks. Each concentration treatment was performed in triplicate. All values were expressed as the mean \pm SD. Cellular reduction of MTT formed a violet crystal formazan through mitochondrial succinate dehydrogenase activity of the viable cells, and the violet crystal formazan was quantified following the methods of Freshney [13]. Percentage of cell viability was calculated using the equation cell viability $(\%)=$ average viable treated cells/average viable negative control cells $\times 100$ ), to reveal the cytotoxicity of the plant extracts. Doses inducing $50 \%$ inhibition of cell viability ( $\mathrm{IC}_{50}$ value) were determined by plotting a graph of the extract concentration against the cell viability. The $\mathrm{IC}_{50}$ value was used for the $\mathrm{LD}_{50}$ calculation Walum [14] to infer hazardous levels, according to the World Health Organization [15].

4. Comet Assay The concentration at $\mathrm{IC}_{50}$ value or the maximum-treated concentration, in the case of no $\mathrm{IC}_{50}$ value, was used in the comet assay to assess the genotoxicity of plant extracts, according to Singh et al. [16]. Shortly, $500 \mu \mathrm{L}$ of cells in media was added with $50 \mu \mathrm{L}$ extracts in a $1.5 \mathrm{~mL}$ microtube, incubated for $24 \mathrm{~h}$ for PBMCs and 24, 48 and $72 \mathrm{~h}$ for cancer cell lines in a humidified $\mathrm{CO}_{2}$ incubator at $37^{\circ} \mathrm{C}$ and $5 \% \mathrm{CO}_{2}$, then the DNA was checked by electrophoresis. The electrophoresis buffer consisted of $0.3 \mathrm{M} \mathrm{NaOH}$ and $1 \mathrm{mM}$ EDTA $(\mathrm{pH}=10)$. The power was supplied at a constant of $3.4 \mathrm{v} / \mathrm{cm}$ with an adjustment to $300 \mathrm{~mA}$, for $25 \mathrm{~min}$. To quantify the level of DNA damage, the extent of DNA migration was defined using the "Olive Tail Moment" (OTM), which is the relative amount of DNA in the tail of the comet multiplied by the median migration distance. The comets were observed at $200 \times$ magnifications and images were obtained using an image analysis system (Isis) attached to a fluorescence microscope (Nikon, Tokyo, Japan), equipped with a $560 \mathrm{~nm}$ excitation filter, $590 \mathrm{~nm}$ barrier filter, and a CCD video camera PCO (Germany). At least 150 cells (50 cells for each of triplicate slides) were examined for each experiment. The CASP software (Wroclaw, Poland) was used to analyze the OTM. The negative control was untreated cells, and the positive control was UV-treated cells. All experiments were in triplicate. The triplicate cultures were scored for the experiment. All values were expressed as the median \pm S.D. The nonparametric Mann-Whitney $U$ test was used for statistical analysis of the comet assay results; statistical significance was set at $p<0.05$.

\subsection{Biological Activity Testing of the Plant Extracts on HepG2 and HCT-116 Compared to Cisplatin}

Dioscorea depauperata and D. glabra leaf extract (stock extract) were prepared, using the same concentration of $1.53 \mathrm{mg} / \mathrm{mL}$, which is the highest working concentration for DNA breaking $(1.42,1.53 \mathrm{mg} / \mathrm{mL}$, results from the MTT assay). The concentration was 10 -fold diluted as $1.53 \times 10^{-1}, 1.53 \times 10^{-2}, 1.53 \times 10^{-3}$ and $1.53 \times 10^{-4} \mathrm{mg} / \mathrm{mL}$ with distilled water. Cisplatin as an anticancer chemical was prepared with a normal saline solution-derived working concentration at $1.00,1.00 \times 10^{-1}, 1.00 \times 10^{-2}, 1.00 \times 10^{-3}$ and $1.00 \times 10^{-4} \mathrm{mg} / \mathrm{mL}$. The substance was purchased from Srinagarind hospital, Khon Kaen University, Thailand. 
Preparations of cancer cell lines, HepG2 and HCT-116 cell lines were purchased from American type culture collection (ATCC). The cell lines were cultured by Dulbecco's Modified Eagle medium low glucose supported with 10\% fetal bovine serum and 1\% antibiotic (streptomycin and penicillin). When the cells grew and flowed on the surface of the $25 \mathrm{~cm}^{2}$ flask, the cells were cultured and subcultured until 10 passages. The trypsin was used for trypsinization. A total of $1 \mathrm{~mL}$ of trypsin was added to the flask and soaked for 2-3 min. An auto pipette was used to gently suck cells and transfer them into a $15 \mathrm{~mL}$ tube that contained $3 \mathrm{~mL}$ medium and were centrifuged at $1800 \mathrm{rpm} 5 \mathrm{~min}$. The supernatant was discarded then we added $3 \mathrm{~mL}$ of the fresh medium into the tube. The cells were gently resuspended and $100 \mu \mathrm{L}$ was sucked into a $1.5 \mathrm{~mL}$ tube. The cells were mixed with $0.1 \mu \mathrm{L}$ erythrosine, then counted by hemocytometer. The $0.4 \times 10^{6}$ cells $/ \mathrm{mL}$ were used for the MTT and comet assay. After cell preparations, $125 \mu \mathrm{L}$ of cells suspended was seeded in 96-well plates. HCT-116 was incubated at $37^{\circ} \mathrm{C}$ and $5 \% \mathrm{CO}_{2}$ for $24 \mathrm{~h}$ and HepG2 for $48 \mathrm{~h}$. After 24 and $48 \mathrm{~h}$, the culture medium was replaced with the fresh medium. Biological activity testing of the plant extracts on HepG2 and HCT-116 compared to cisplatin was performed using the MTT and comet assays.

\subsection{Biological Activity Testing for Pesticidal Efficiency}

Pesticidal efficiency of the Dioscorea species extracts were tested on Brassica chinensis. There were four experiments with two controls. Control A is B. chinensis extract-untreated individuals. Control B was the plants treated with extract of D. bulbifera, the species which was not toxic to PBMCs on both cell and DNA levels. The sample experiments were the plants treated with extracts of D. depauperata (sample C) and D. glabra (sample D) which shown effect on DNA damage. The B. chinensis seeds were cultivated in 40 pots, retained in the nursery. When geminated, each pot was thinned to have three individuals. The pots were separated into four experiments of 10 pots, each experiment being the control A, control treatment $B$, and experimental treatment samples $C$ and $D$, respectively. A total of $200 \mathrm{~g}$ of fresh leaves of $D$. depauperata and D. glabra was ground with $1 \mathrm{~L}$ of water solvent (at a rate 1:5) and added with the $5 \mathrm{~mL}$ of surfactant (tween 20). The extracts were used in the next steps or stored in a refrigerator until further used. The four groups of 10 pots each of 25-day-old B. chinensis were moved from the nursery outside to the field, then the three $B$. chinensis individuals of each pot were sprayed with the extracts of the controls A and B, and treatment samples $C$ and $D$. The spraying was done five times, once a week. Once the $B$. chinensis reached 60 days old, they were examined for holes from insect bites, and scored as $0,1,2$ and 3 indicating that $0,1,2$, or 3 B. chinensis individuals were destroyed.

\section{Conclusions}

Lidocaine is the predominant substance of the genus Dioscorea in Thailand, as used in plant systematics. The two species, D. depauperata and D. glabra may be used for human hepatocyte cancer treatment, with insect protection applied as an alternative pesticide without fermenting to the vegetable. The Dioscorea species containing lidocaine or with extracted lidocaine can be applied to natural product creation used for medical and public health.

Author Contributions: W.W. performed the experiments, analyzed data, and wrote the manuscript (original draft). A.C. conceptualized, acquired funding, supervised, and wrote the manuscript (reviewed and edited). P.S. provided plant materials and performed data validation. R.S. provided experimental design and project administration. T.T. supervised the experimental design, performed data validation, and wrote the manuscript (reviewed and edited). All authors have read and agreed to the published version of the manuscript.

Funding: Warin Wonok and Arunrat Chaveerach are funded by the Thailand Research Fund and Khon Kaen University through the Royal Golden Jubilee Ph.D. Program (Grant No. PHD/0194/2558). Additionally, this research was partially funded by Research and Academic Services, Khon Kaen University.

Data Availability Statement: Not applicable. 
Conflicts of Interest: The funders had no role in the design of the study; in the collection, analyses, or interpretation of data; in the writing of the manuscript, or in the decision to publish the results.

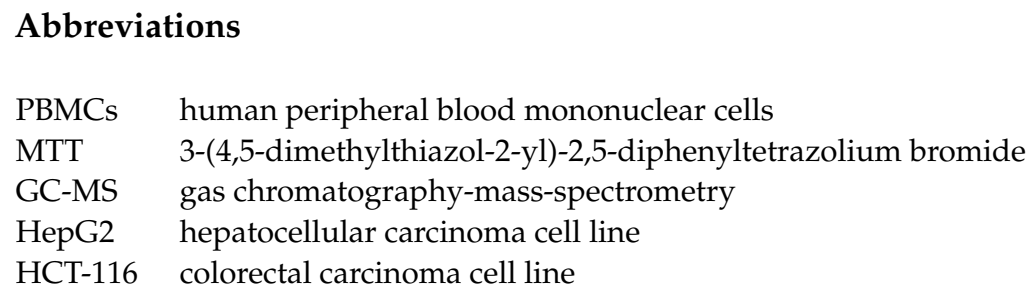

\section{References}

1. Wilkin, P.; Thapyai, C. Dioscoreaceae. In Flora of Thailand Vol. 10 Part 1; Forest Herbarium, Royal Forest Department: Bangkok, Thailand, 2009; pp. 1-140, ISBN 978-974-286-614-3.

2. Maneenoon, K. Medicinal Plants of the Genus Dioscorea L. Used in Traditional Thai Medicine Prescriptions. KKU Sci. J. 2013, 41, 797-807.

3. Jesus, M.; Martins, A.P.J.; Gallardo, E.; Silvestre, S. Diosgenin: Recent Highlights on Pharmacology and Analytical Methodology. J. Anal. Methods Chem. 2016, 2016, 1-16. [CrossRef] [PubMed]

4. Shen, L.; Xu, J.; Luo, L.; Hu, H.; Meng, X.; Li, X.; Chen, S. Predicting the Potential Global Distribution of Diosgenin-Contained Dioscorea Species. Chin. Med. 2018, 13, 1-10. [CrossRef] [PubMed]

5. Hazrati, K.; Sapuan, S.; Zuhri, M.; Jumaidin, R. Extraction and Characterization of Potential Biodegradable Materials Based on Dioscorea hispida Tubers. Polymers 2021, 13, 584. [CrossRef] [PubMed]

6. Kumar, S.; Das, G.; Shin, H.-S.; Patra, J.K. Dioscorea spp. (A Wild Edible Tuber): A Study on Its Ethnopharmacological Potential and Traditional Use by the Local People of Similipal Biosphere Reserve, India. Front. Pharmacol. 2017, 8, 52. [CrossRef] [PubMed]

7. Ikiriza, H.; Ogwang, P.E.; Peter, E.L.; Hedmon, O.; Tolo, C.U.; Abubaker, M.; Abdalla, A.A.M. Dioscorea bulbifera, a Highly Threatened African Medicinal Plant, A Review. Cogent Biol. 2019, 5. [CrossRef]

8. Padhan, B.; Panda, D. Potential of Neglected and Underutilized Yams (Dioscorea spp.) for Improving Nutritional Security and Health Benefits. Front. Pharmacol. 2020, 11, 496. [CrossRef] [PubMed]

9. Gordh, T.; Torsten, E.; Gordh, M.D.; Lindqvist, K. Lidocaine: The Origin of a Modern Local Anesthetic. J. Am. Soc. Anesthesiol. 2010, 113, 1433-1437. [CrossRef] [PubMed]

10. Golzari, S.; Soleimanpour, H.; Mahmoodpoor, A.; Safari, S.; Ala, A. Lidocaine and Pain Management in the Emergency Department: A Review Article. Anesthesiol. Pain Med. 2014, 3, e15444. [CrossRef] [PubMed]

11. Panyakhamlerd, Y.; Sirivararom, P.; Chaisen, N.; Turnprakiat, S. A Comparative Study of the Effectiveness of $10 \%$ Lidocaine Spray at Oropharyngolarynx Plus Tracheal Tube Cuff Versus Oropharyngolarynx Alone in Attenuation of the Hemodynamic Response During Direct Laryngoscopy and Intubation in Controlled Hypertensive Patients. Thai. J. Anesthesiol. 2013, 39, $292-301$.

12. Prapanbandit, N. Trigger Point Injection with $1 \%$ Versus $2 \%$ Lidocaine for Treatment of Myofascial Pain Syndrome at Neck and Upper Back: A Randomized Controlled and Double-blinded Clinical Trial. ASEAN J. Rehabil. Med. 2019, 29, 99-106.

13. Freshney, R.I. Culture of Animal Cells: A Manual of Basic Technique and Specialized Applications, 6th ed.; John Wiley \& Sons: Hoboken, NJ, USA, 2010; pp. 1-796, ISBN 978-047-052-812-9.

14. Walum, E. Acute Oral Toxicity. Environ. Health Perspect. 1998, 106, 497. [CrossRef] [PubMed]

15. World Health Organization. The WHO Recommended Classification of Pesticides by Hazard and Guidelines to Classification 2009. Available online: https://apps.who.int/iris/handle/10665/44271 (accessed on 21 January 2021).

16. Singh, N.P.; McCoy, M.T.; Tice, R.R.; Schneider, E.L. A Simple Technique for Quantitation of Low Levels of DNA Damage in Individual Cells. Exp. Cell Res. 1988, 175, 184-191. [CrossRef] 